Andrei Orlov

Marquette University

Milwaukee

\title{
"THE LEARNED SAVANT \\ WHO GUARDS THE SECRETS \\ OF THE GREAT GODS»: \\ EVOLUTION OF THE ROLES AND TITLES \\ OF THE SEVENTH ANTEDILUVIAN HERO \\ IN MESOPOTAMIAN \\ AND ENOCHIC TRADITIONS \\ (Part I: Mesopotamian Traditions) ${ }^{*}$
}

«... They gave him the tablet of the gods ... a secret of heaven and [underworld],

They put in his hand the cedar[-rod], beloved of the great gods ... ... the learned savant who guards the secrets of the great gods».

Tablet from Nineveh

\section{Introduction}

Recent history, especially after the discovery of the Dead Sea Scrolls, has witnessed to a renewed interest in the intertestamental Jewish literature and a recognition of its importance for the understanding of early Christian texts and traditions. These Jewish materials, not included in the canon of the Old Testament, and known to scholars as the Old Testament Pseudepigrapha (a collective term for anonymous Jewish literary remains written between $4^{\text {th }}$ cent. B.C. and $2^{\text {nd }}$ cent. A.D. in response to the biblical materials and later preserved by the Christian communities), are viewed by scholars as significant sources for understanding the traditions of the exalted patriarchs and prophets such as Enoch, Abraham, Melchizedek, Jacob, Moses, and others that played a significant role in patristic and rabbinic theological arguments. This article deals with one of such cluster of pseudepigraphic traditions associated with the name of the seventh antediluvian patriarch Enoch which had its roots in the Mesopotamian lore.

\footnotetext{
* To be continued in: Scrinium II. Universum Hagiographicum (forthcoming).
} 


\section{King Enmeduranki}

Even a brief look at early Enochic booklets such as the Book of the Watchers and the Astronomical Book demonstrates that already in these early Enochic writings the seventh antediluvian patriarch appears to have a set of highly developed roles: a sage, a visionary, a diviner, and a scribe. One can see these descriptions of the main character as a product of a substantial and long-lasting conceptual development. However, for anyone familiar with the early biblical traditions about the patriarch Enoch found in Genesis, the surprising wealth of information about the seventh antediluvian patriarch that is found in the earliest booklets of 1 Enoch might be puzzling; for the biblical account associated with the priestly source of Genesis does not provide a great deal of material about the aforementioned Enochic roles. Gen 5:21-24 informs us that «when Enoch had lived sixty-five years he became the father of Methuselah. He walked with God after the birth of Methuselah three hundred years, and had other sons and daughters. Thus all the days of Enoch were three hundred sixty-five years. Enoch walked with God; then he was no more, because God took him».1

While the passage from Genesis shows Enoch in his important family role, almost nothing is said about his other prominent celestial roles, although the priestly author exhibits familiarity with Enoch's status as a translated figure by mentioning his removal from the earth. In view of the scarcity of information in the Genesis account about the heavenly roles and titles of the seventh antediluvian patriarch and the complexity of these roles and titles in the early Enochic writings, scholars have been searching for other possible factors contributing to this evolution. ${ }^{2}$ They draw attention to some Mesopotamian traditions which, in their opinion, might have helped to enhance or even shape the profile of the seventh antediluvian hero.

In the $20^{\text {th }}$ cent. the influence of the Mesopotamian traditions on the Enochic materials has been the subject of several major publications, including the studies of Heinrich Zimmern, H. Ludin Jansen, Pierre Grelot, Otto Neugebauer, James VanderKam, and Helge S. Kvanvig. ${ }^{3}$ The most important for this

${ }^{1}$ All biblical citations will be taken from New Revised Standard Version.

${ }^{2} \mathrm{M}$. Stone highlights that «what is significant is the fact that outside the Bible this figure [Enoch] first comes into the light of history full-grown. Enoch appears in all his complexity in the two Enochic writings which are the oldest (the Book of the Watchers and the Book of the Luminaries). It is to this developed Enoch figure that the angel Uriel shows the secrets of heavenly bodies and their movements». M. E. STONE, «Enoch, Aramaic Levi and Sectarian Origins», Journal for the Study of Judaism 19/2 (1988), 159-170, esp. 163.

${ }^{3}$ H. Zimmern, «Urkönige und Uroffenbarung», in: E. Schrader (ed.), Die Keilinschriften und das Alte Testament, Berlin 1902-1903, vol. 2, 530-543; H. LUdIN JANSEN, Die Henochgestalt: Eine vergleichende religionsgeschichtliche Untersuchung, Oslo 
investigation are the books of VanderKam and Kvanvig since these are based on the recent publications of the cuneiform sources from Mesopotamia.

Before proceeding to the Mesopotamian evidence, one should note that it is impossible within the limited scope of this present work to investigate all the Mesopotamian influences which have contributed to the formation of the Enochic roles and titles. This work, therefore, will mainly concentrate on one of these formative influences, the tradition about the seventh antediluvian king Enmeduranki. ${ }^{4}$ In my judgment, the Enmeduranki tradition provides a sharp illustration of the fact that the celestial roles of this Mesopotamian hero served as a decisive pattern for the future heavenly roles of his Jewish counterpart, the patriarch Enoch. Another reason that the choice is limited to investigating this Mesopotamian character is that in all recent studies on the Mesopotamian prototypes of Enoch, the Enmeduranki tradition has remained in the center of scholarly debate. ${ }^{5}$

Salient witnesses to the Enmeduranki tradition include the various versions of the so-called Sumerian antediluvian King List, in recensions dated from 1500 B.C. to 165 B.C. ${ }^{6}$ The List demonstrates a number of similarities

1939 (Norske Videnskaps-Akademi i Oslo II. Hist.-Filos. Klasse, 1); P. Grelot, «La légende d'Hénoch dans les apocryphes et dans la Bible: Origine et signification», Recherches de science religieuse 46 (1958), 5-26, 181-210; O. Neugebauer, «The 'Astronomical' Chapters of the Ethiopic Book of Enoch (72 to 82)», in: M. Black, The Book of Enoch or 1 Enoch, Leiden: Brill 1985 (Studia in Veteris Testamenti pseudepigrapha, 7), 386-412; J. C. VANDERKAM, Enoch and the Growth of an Apocalyptic Tradition, Washington, DC, 1984 (The Catholic Biblical Quarterly Monograph Series, 16); H. S. Kvanvig, Roots of Apocalyptic: the Mesopotamian Background of the Enoch Figure and of the Son of Man, Neukirchen-Vluyn 1988 (Wissenschaftliche Monographien zum Alten und Neuen Testament, 61).

${ }^{4}$ Zimmern's research was the first in-depth scholarly attempt to trace the connection between Enoch and Enmeduranki. See Zimmern, Die Keilinschriften und das Alte Testament, vol. 2, 540.

${ }^{5}$ VAnderKam, Enoch and the Growth of an Apocalyptic Tradition, 33ff.; KvanviG, Roots of Apocalyptic, 184ff.; J. J. Collins, «Sage in the Apocalyptic and Pseudepigraphic Literature», in: J. G. Gammie — L. G. Perdue (eds.), The Sage in Israel and the Ancient Near East, Winona Lake, IN, 1990, 343-354, esp. 344-347; ID., Seers, Sybils and Sages in Hellenistic-Roman Judaism, Brill 2001 (Supplements to the Journal of the Study of Judaism, 54), 44ff.

${ }^{6}$ On the Sumerian King List, see S. Langdon, «The Chaldean Kings before the Flood», Journal of the Royal Asiatic Society of Great Britan and Ireland 42 (1923), 251-259; ID., Oxford Edition of Cuneiform Texts, vol. 2, Oxford: Clarendon, 1923; T. Jacobsen, The Sumerian King List, Chicago, IL, 1939 (Oriental Institute of the University of Chicago, Assyrological Studies, 11); F. R. KRAUS, «Zur Liste der älteren Könige von Babylonien», Zeitschrift für Assyriologie NF 16 [50] (1952), 29-60; J. J. FInKELSTEIN, «The Antediluvian Kings: A University of California Tablet», Journal of Cuneiform Studies 17 (1963), 39-51. 
with the genealogy of Gen 5. One of the significant details found in the List is that Mesopotamian kings, similar to the patriarchs from the Genesis account, had extraordinarily long reigns, ranging from 3,600 to 72,000 years. Another important feature is that the two versions of the List account for ten kings, the last of whom is designated as the hero of the flood. This fact recalls the role of Noah who occupies the tenth place in the list of Gen 5. J. VanderKam notes that «in the literature on Genesis 5 there is a well-established tradition which holds that $\mathrm{P}$ modeled his pre-flood genealogy on a Mesopotamian list of antediluvian kings, the so-called Sumerian King List».7 An intriguing character in the Sumerian King List is Enmeduranki (Enmeduranna), the king of Sippar, the city of the sun-god Shamash. ${ }^{8}$ In three copies of the List, he occupies the seventh place, which in the Genesis genealogy belongs to Enoch. Moreover, in other Mesopotamian sources Enmeduranki appears in many roles and situations which demonstrate remarkable similarities with Enoch's story. VanderKam's research shows that the priestly author responsible for the biblical portrayal of Enoch in Gen 5:21-24 was aware of these broader Mesopotamian traditions which served as a prototype for Enoch's figure, whose symbolical age of 365 years reflects the link between the patriarch and the solar cult of Shamash.

Scholars have convincingly demonstrated that Enmeduranki's story was an important source for the biblical portrait of Enoch and for his portrayals in the earliest Enochic pseudepigrapha. ${ }^{9}$ VanderKam's research demonstrated that the two texts, namely Gen 5:21-24 and the Astronomical Book, possibly the most ancient extant sources related to Enoch, have a strong connection with the Mesopotamian lore. He also remarks that later Enochic booklets became increasingly influenced by biblical and Hellenistic settings, and, therefore, primeval features of the Mesopotamian lore took there a new form. ${ }^{10}$

The Enmeduranki tradition was preserved in a number of texts, the most important of which is a tablet from Nineveh published by Wilfred Lambert which could be dated before 1100 B. C. ${ }^{11}$ The material is crucial for the current study. The text, taken from Lambert's edition, reads as follows:

\footnotetext{
${ }^{7}$ VanderKam, Enoch and the Growth of an Apocalyptic Tradition, 26.

${ }^{8}$ Grelot, «La légende d'Hénoch dans les apocryphes et dans la Bible: Origine et signification», 187.

${ }^{9}$ VanderKam, Enoch and the Growth of an Apocalyptic Tradition; Kvanvig, Roots of Apocalyptic; J. Collins observes that «to a great extent he [Enoch] is modeled on the mythological figure of Enmeduranki, founder of the $b \bar{a} r \hat{u}$ guild of diviners and omen interpreters. The correspondences are already in evidence in Genesis». Collins, «The Sage in Apocalyptic and Pseudepigraphic Literature», 345.

${ }^{10}$ VanderKam, Enoch and the Growth of an Apocalyptic Tradition, 189.

${ }^{11}$ Kvanvig, Roots of Apocalyptic, 190.
} 
1. Šamaš in Ebabbara [appointed]

2. Enmeduranki [king of Sippar],

3. the beloved of Anu, Enlil [and Ea].

4. Šamaš and Adad [brought him in] to their assembly,

5. Šamaš and Adad [honored him],

6. Šamaš and Adad [set him] on a large throne of gold,

7. They showed him how to observe oil on water, a mystery of Anu, [Enlil and Ea],

8. They gave him the tablet of the gods, the liver, a secret of heaven and [underworld],

9. They put in his hand the cedar[-rod], beloved of the great gods.

10. Then he, in accordance with their [word(?)] brought

11. the men of Nippur, Sippar and Babylon into his presence,

12. and he honored them. He set them on thrones before [him],

13. he showed them how to observe oil on water, a mystery of Anu, Enlil and Ea,

14. He gave them the tablet of the gods, the liver, a secret of heaven and underworld,

15. He put in their hand the cedar[-rod], beloved of the great gods.

16. $\{$ The tablet of the gods, the liver, a mystery of heaven and underworld;

17. how to observe oil on water, a secret of Anu, Enlil and Ea;

18. «that with commentary», When Anu, Enlil; and how to make mathematical calculations.

19. The learned savant, who guards the secrets of the great gods,

20. will bind his son whom he loves with an oath

21. before Šamaš and Adad by tablet and stylus and

22. will instruct him. When a diviner,

23. an expert in oil, of abiding descent, offspring of Enmeduranki, king of Sippar,

24. who set up the pure bowl and held the cedar[-rod],

25. a benediction priest of the king, a long-haired priest of Šamaš

26. as fashioned by Ninhursagga,

27. begotten by a nišakku-priest of pure descent:

28. if he is without blemish in body and limbs

29. he may approach the presence of Šamaš and Adad where liver inspection and oracle (take place). ${ }^{12}$

12 W. G. LAmbert, «Enmeduranki and Related Matters», Journal of Cuneiform Studies 21 (1967), 126-138, esp. 132. Another bit of evidence related to the Enmeduranki tradition is the first-person statement of Nebuchadnezzar I. The text can be dated to his reign between 1125 B. C. and 1104 B. C. The material demonstrates a number of parallels to the text from Nineveh. It reads as follows: «....king of Babylon who supervises all the cult-centers and confirms the regular offerings, am I, distant scion of kingship, seed preserved from before the flood, offspring of [Enmeduranki], king of Sippar, who set up the pure bowl and held the cedar-wood (rod), who sat in the presence of Shamash and Adad, the divine adjudicators, foremost son, [...], king of justice, reliable shepherd, who keeps the land's foundations secure». LAMBERT, «Enmeduranki and Related Matters», 130. 
This text carries great weight in the investigation of the roles and titles of the seventh antediluvian hero for two reasons. First, it provides a valuable sketch of the roles of its main hero, the seventh antediluvian king Enmeduranki, roles this character has acquired during his interactions with human and divine beings in the terrestrial and celestial realms. Later analysis will show that Enmeduranki's roles appear to be very similar to Enoch's functions and duties as they are presented in the early Enochic traditions.

Second, the tablet from Nineveh also reveals the seventh antediluvian hero's earthly and celestial titles, attesting him as a «learned savant», a «diviner», a «priest», and a «guardian of secrets». Some of these appellations represent the earliest counterparts of the later titles of Enoch and Metatron in Jewish traditions. The analysis now proceeds to a close investigation of Enmeduranki's roles and titles as they are attested in the tablet from Nineveh.

\section{Enmeduranki as the Diviner}

Leo Oppenheim argues that the importance of divination in Mesopotamian culture(s) can be shown by the large number of the preserved omen collections; these collections range in time from the late Babylonian period up to the time of the Seleucid kings. ${ }^{13}$ Mesopotamian divination, in Oppenhem's opinion, can be understood as «a technique of communication with the supernatural forces that are supposed to shape the history of the individual as well as that of the group». ${ }^{14}$ Divination presupposed the belief that these forces are able and sometimes willing to communicate their intentions since they are interested in the well-being of the individual or the group. ${ }^{15}$

The art of divination in the Mesopotamian religious environment was practiced by several groups of highly trained professionals. One of the most prominent and frequently mentioned groups is the bāru guild, a group of oracle-priests. ${ }^{16}$ James VanderKam suggests that the title of this enigmatic

${ }^{13}$ L. Oppenheim, Ancient Mesopotamia: Portrait of a Dead Civilization, Chicago: The University of Chicago Press, 1964, 206.

${ }^{14}$ Oppenheim, Ancient Mesopotamia: Portrait of a Dead Civilization, 207.

${ }^{15}$ Ibid.

${ }^{16}$ On the bārû guild, see H. ZIMMERn, Beiträge zur Kenntnis der babylonischen Religion. Die Beschwörungstafeln šurpu. Ritualtafeln für den Wahrsager, Beschwörer, und Sänger, Leipzig 1896-1901 (Assyriologische Bibliothek, 12), 86-87; A. HALDAR, Associations of Cult Prophets Among the Ancient Semites, Uppsala: Almkwist \& Wiksell, 1945, 1ff.; J. RENGER, «Untersuchungen zum Priestertum in der altbabylonischen Zeit», Zeitschrift für Assyriologie 59 (1969), 203-204; OPPENHEIM, Ancient Mesopotamia: Portrait of a Dead Civilization, 212ff.; VANDERKAM, Enoch and the Growth of an Apocalyptic Tradition, 56; M. S. Moore, The Balaam Traditions: Their Character and Development, Atlanta, GA, 1990 (Society of Biblical Literature / Dissertation Series, 113), 41-46. 
group derives from the Akkadian verb barû, which means «to see, to observe». ${ }^{17}$ Among the divination techniques used by the $b \bar{a} r u \hat{u}$ practitioners are the observation of omens connected with the interpretations of configurations of oil in water, the patterns of rising smoke, the conditions of internal organs of sacrificial animals, and mantic dreams.

The text from Nineveh refers to som e of these procedures often used in Mesopotamian divination such as lecanomancy, an observation of oil in water, and hepatoscopy, an inspection of the liver of the sacrificial animal. It also mentions another, apparently even more enigmatic technique involving the use of a cedar[-rod].$^{18}$ References to these divinatory rites are repeated many times in the text, first as a special knowledge (a divine secret, «a mystery of Anu, Enlil and Ea») which was passed to Enmeduranki (or, literally, «shown [ušabrû] to him») by the deities Shamash and Adad, ${ }^{19}$ and then as the mysteries transmitted by Enmeduranki to some humans, including his son $^{20}$ and then practiced routinely by diviners. ${ }^{21}$

The full meanings of these divinatory procedures as means of communication with the upper realm are shrouded in mystery. Mesopotamian sources,

${ }^{17}$ VanderKam, Enoch and the Growth of an Apocalyptic Tradition, 56. See also Haldar, Associations of Cult Prophets, 1. Alfred Haldar observes that bārû is «usually interpreted "seer", "visionary" in general, without reference to any special mode of divination».

${ }^{18}$ Wilfred Lambert observes that it represents «an oftmentioned ritual appurtenance, the function of which is no longer understood». LAMBERT, «Enmeduranki and Related Matters», 127. For the possible meanings of this ritual, see E. J. WILSON, «A Note on the Use of erinnu in bārû-Rituals», Journal of the Ancient Near Eastern Society 23 (1995), 95-98. See also Zimmern, Die Keilinschriften und das Alte Testament, 533 , n. 5.

${ }^{19}$ vv. 7-8 «...They [Šamaš and Adad] showed him how to observe oil on water, a mystery of Anu, [Enlil and Ea], they gave him the tablet of the gods, the liver, a secret of heaven and [underworld]...». LAMBERT, «Enmeduranki and Related Matters», 132.

${ }^{20}$ vv. 13-17 «...he showed them how to observe oil on water, a mystery of Anu, Enlil and Ea, he gave them the tablet of the gods, the liver, a secret of heaven and underworld, he put in their hand the cedar[-rod], beloved of the great gods. The tablet of the gods, the liver, a mystery of heaven and underworld; how to observe oil on water, a secret of Anu, Enlil and Ea...». LAMBERT, «Enmeduranki and Related Matters», 132.

${ }^{21}$ vv. $22-29$ «...When a diviner, an expert in oil, of abiding descent, offspring of Enmeduranki, king of Sippar, who set up the pure bowl and held the cedar[-rod], a benediction priest of the king, a long-haired priest of Shamash as fashioned by Ninhursagga, begotten by a nišakku-priest of pure descent if he is without blemish in body and limbs he may approach the presence of Shamash and Adad where liver inspection and oracle (take place)». LAMBERT, «Enmeduranki and Related Matters», 132. 
however, give at least some hints about how the external side of these procedures was carried out. During the lecanomancy procedure, a diviner, a bār $\hat{u}$ practitioner, normally poured oil in a bowl of water held on his lap..$^{22}$ The movements of oil in water, in its relation to the surface of the bowl and its rim, and the formation and the color of oil were then interpreted ${ }^{23}$ in relation to the appropriate political, military or personal situations. ${ }^{24}$

Hepatoscopy was an attempt to communicate with the deity through the medium of the body of an animal slaughtered for this purpose. ${ }^{25}$ Usually the hepatoscopy ritual was a part of a more complex rite of extispicy in which several animal organs, including the windpipe, the lungs, the liver (considered the seat of the soul), ${ }^{26}$ and the gall bladder were explored. The $b \bar{a} r \hat{u}$ practitioner normally began the ritual by petitioning the oracle gods, Shamash and Adad, asking them to inscribe their message upon the entrails of the animal. Then, through the exploration of the inner parts of the animal, the diviner made predictions «based on atrophy, hypertrophy, displacement, special markings, and other abnormal features of the organs». ${ }^{27}$ Leo Oppenheim observes that early Mesopotamian hepatoscopy apparently was a technique of a binary, yes-or-no level. Numerous models of the liver made of clay found on various Mesopotamian sites point to the popularity of this technique in the cultures of this region. ${ }^{28}$ Michael Moore observes that generally the ritual of extispicy was so expensive that only royal persons and nobles could afford it. It was also regarded as the most reliable divinatory technique and was often employed as a check on all others. ${ }^{29}$

22 Oppenheim, Ancient Mesopotamia: Portrait of a Dead Civilization, 212.

${ }^{23}$ One of the Mesopotamian texts cited by Michael Moore provides an example of such interpretation: «If the oil divides into two; for a campaign, the two camps will advance against each other; for treating a sick man, he will die. If the flour, in the east, takes the shape of a lion's face, the man is in the grip of a ghost of one who lies in the open country; the sun will consign it (the host) to the wind and he will get well». Moore, The Balaam Traditions: Their Character and Development, 43.

${ }^{24}$ Oppenheim, Ancient Mesopotamia: Portrait of a Dead Civilization, 212; ID., The Interpretation of the Dreams in the Ancient Near East, with a Translation of an Assyrian Dream-Book (Transactions of the American Philosophical Society, 46.3; Philadelphia, American Philosophical Society, 1956), 242.

${ }^{25}$ Oppenheim, Ancient Mesopotamia: Portrait of a Dead Civilization, 212.

${ }^{26}$ Haldar, Associations of Cult Prophets, 6; G. Contenau, La divination chez les Assyriens et les Babyloniens, Paris: Payot, 1940, 235ff.

${ }^{27}$ Oppenherm, Ancient Mesopotamia: Portrait of a Dead Civilization, 212.

${ }^{28}$ Moore, The Balaam Traditions: Their Character and Development, 42.

${ }^{29}$ Moore, The Balaam Traditions: Their Character and Development, 42. See also J. Nougayrol, «La divination babylonienne», in: A. Caquot - M. Leibovici (eds.), La Divination, Paris: Presses Universitaires de France, 1968, 25-81, esp. 38. 
A significant feature of the tablet from Nineveh is that Enmeduranki acquired his expertise in the divinatory arts directly from Shamash and Adad. Both of these deities are traditionally associated with knowledge of divination and are sometimes called «lords of oracles». More commonly, Shamash is referred to as the «lord of decisions» and Adad as the «lord of the oracle/ omen». ${ }^{30}$

\section{Enmeduranki as the Expert in Secrets}

In the previous section it was pointed out that the text from Nineveh refers to particular knowledge about the divinatory procedures transmitted to Enmeduranki in the course of his visitation of the divine assembly. It is intriguing that when the tablet from Nineveh refers to this divinatory knowledge, it uses vocabulary that specifically stresses the esoteric character of the information which the seventh antediluvian king received during his initiations in the celestial realm. Before proceeding to a close analysis of this distinct terminology, I must make general comments about Enmeduranki's initiation into celestial knowledge.

First, some attention must be paid to the level of initiation. The text stresses that Enmeduranki enjoys special relationships with three chief gods Anu, Enlil and Ea. He is defined as their «beloved» (narāmu), an important title which signals the particular type of relationship between the initiate and the deities. ${ }^{31}$ It is noteworthy that he was brought ( $\left.\check{s} \bar{u} r u b u\right)$ to the inner circle of the celestial community (the divine assembly) by gods themselves, namely the deities responsible for natural phenomena - the solar deity Shamash and deity of weather Adad. The reference to the deities of luminaries and weather anticipates here the later Enochic legends in which the seventh antediluvian hero is initiated by the angel Uriel into astronomical and meteorological lore. ${ }^{32}$

A second significant detail of Enmeduranki's initiation is that the hero is described as the one who has a seat («a large throne of gold») in heaven, which indicates his elevated status and possibly a newly acquired celestial

${ }^{30} \mathrm{~V}$ AnderKam, Enoch and the Growth of an Apocalyptic Tradition, 58.

${ }^{31}$ Later rabbinic materials often apply this title to Enoch. Thus Peshikta de Rav Kahana defines Enoch as «beloved». In Midrash Ha-Gadol Enoch is defined as the «Beloved Seventh».

32 James VanderKam traces another similarity with the Enochic tradition. He observes that Enoch's entry into God's throne room in chapter 14 of the Book of the Watchers «is reminiscent of Enmeduranki's admission to the presence of Shamash and Adad, but, while the ancient king there learned divinatory techniques, Enoch is told in a forthright way (though in a dream - a common mantic medium) what will befall the angels who had sinned». VANDERKAM, Enoch and the Growth of an Apocalyptic Tradition, 131. 
rank of the initiate. Kvanvig observes in relation to this detail that the fact that Enmeduranki «is seated on a golden throne among the gods ... must mean that he was included in their assembly».33

A third significant feature is that the knowledge Enmeduranki received in the assembly of the gods is explicitly labeled as esoteric: the text refers to the «secrets» and «mysteries» acquired by the seventh antediluvian king. This terminology is applied to the knowledge about the divinatory procedures, the rituals of lecanomancy and hepatoscopy. ${ }^{34}$ In the text the phrase «how to observe oil on water» is followed by the expression «a mystery (nisirtu) ${ }^{35}$ of Anu, Enlil and Ea» and the phrase «the tablet of the gods, the liver» (which possibly refers to a tablet of liver omens ${ }^{36}$ ) is followed by the expression «a secret (pirištu) ${ }^{37}$ of heaven and earth». Both clauses are repeated later in verses 13-14 and 16-17. In verses 16-17 the words «mystery» and «secrets» have changed places: «a mystery of heaven and underworld» and «a secret of Anu, Enlil and Ea», indicating that both terms are used interchangeably by the authors (or editors) of the text. ${ }^{38}$

Several words should be said about the tablet (tuppu) first identified as «a secret of heaven and underworld» (vv. 8 and 14) and later as «a mystery of heaven and underworld» (v. 16). Helge Kvanvig observes that the language of the tablet emphasizes the esoteric character of the divine wisdom revealed to Enmeduranki, reinforced by such terms as nișirtu (mystery) and purištu (secret). ${ }^{39}$ The esoteric character of the knowledge received by Enmeduranki and then transmitted to the $b \bar{a} r \hat{u}$ guild is also underscored in the text by a reference to the oath which precedes the king's instructions to his son.

Another important detail of the tradition about the tablet that might point to the content of this esoteric knowledge is the juxtaposition of the terms «secrets» and «mysteries» with the phrases «heaven and underworld» or «heaven and earth». Kvanvig points out that both phrases possibly have cosmological meaning. ${ }^{40}$ Intended to describe the totality of creation, this terminolo-

${ }^{33}$ Kvanvig, Roots of Apocalyptic, 187.

${ }^{34}$ Alfred Haldar observes that «the secret of divination is thus to be regarded as a secret knowledge confined to the priesthood and in which the uninitiated could have no share». Haldar, Associations of Cult Prophets, 4.

${ }^{35}$ Helge Kvanvig clarifies that this term means literally «that which is protected». Kvanvig, Roots of Apocalyptic, 188.

${ }^{36}$ Kvanvig, Roots of Apocalyptic, 187.

${ }^{37}$ Literally this term means «that which is separated». Kvanvig, Roots of Apocalyptic, 188.

${ }^{38}$ Kvanvig, Roots of Apocalyptic, 188.

${ }^{39}$ Ibid.

${ }^{40}$ Kvanvig points out that the phrase rendered in the Lambert's translation as a «secret of heaven and underworld» can also be translated as a «secret of heaven and earth». Kvanvig, Roots of Apocalyptic, 188. 
gy can also be related to cosmogonic and creational concepts. The identification of the secrets with cosmological knowledge recalls 2 Enoch, where the notion of secrets is applied solely to the mysteries of God's creation.

The reference to the tablet which crosses the boundaries between heaven and earth in the Nineveh text anticipates later traditions about the celestial tablets found in various Enochic materials. Pierre Grelot points to the terminological similarities between Enoch's heavenly tablets and Enmeduranki's tablets representing the mystery of «heaven and earth» and argues that «Enmeduranki knows "the secret of Anu, of Bel and of Ea" only because Shamash and Adad have delivered unto him "the tablet of the gods, the tablet of the mystery of heaven and earth"; and here one easily recognizes the prototype of the "heavenly tablets" communicated to Enoch». ${ }^{41}$

Finally, a remark must be made about Enmeduranki's titles that the text brings up in conjunction with his expertise in esoteric knowledge. The text from Nineveh defines him as «the learned savant, who guards the secrets of the great gods». Kvanvig observes that this phrase reveals the seventh antediluvian king in at least two roles which appear to be closely interconnected. Enmeduranki is described first as a «learned savant» (ummânu müdu) and second as the «guardian (lit. "guarding») of the secrets (nāssir pirišsti) of the great gods». ${ }^{42}$ The latter title is especially important for this investigation since it establishes a definite background for the future patriarch's role as an יודע רזים יודי (Knower of Secrets) in the Metatron lore. ${ }^{43}$ The dissemination of esoteric information will remain one of the major functions of the seventh patriarch in various Enochic traditions which depict him sharing astronomical, meteorological, calendarical, and eschatological knowledge with his sons and other people during his short visit to earth. Knowledge of secrets will also play a significant part in Metatron's duties in the Merkabah tradition where he will be responsible for transmitting the highest secrets to the Princes under him, as well as to humankind.

\section{Enmeduranki as the Mediator}

On closer examination of the structure of the text from Nineveh, a significant characteristic of this narrative stands out: the tablet emphasizes not only what happened to Enmeduranki in the celestial realm but also what he

\footnotetext{
${ }^{41}$ GRELOT, «La légende d'Hénoch dans les apocryphes et dans la Bible: Origine et signification», 15 .

${ }^{42}$ Kvanvig, Roots of Apocalyptic, 188.

${ }^{43}$ John Collins notes that «Enoch's role as revealer is ... illuminated by the parallel with Enmeduranki. The Sumerian king was admitted into the divine assembly and shown mysteries that included the tablets of heaven and the techniques of divination». CoLLINs, Seers, Sybils and Sages in Hellenistic-Roman Judaism, 45.
} 
did upon his return to earth. The multiple references to his earthly instructions to the people and to his son stress this concern of the authors or editors of the account. The text therefore makes explicit that one of the most important functions of the initiated Enmeduranki is transmission of the knowledge that he received from the deities to inhabitants of the terrestrial realm. This account of the mediation of knowledge is similar to later Enochic traditions. Just like Enmeduranki, who transmitted knowledge to the people of Nippur, Sippar and Babylon and to his son, Enoch later would share the esoteric lore that he received from Uriel and God with humans and with his son Methuselah. Both traditions stress the pattern of mediation (Deity/angels - Enmeduranki/Enoch - people/son) in which Enmeduranki/Enoch occupies the pivotal role of a middleman. In the text from Nineveh, the instructions given to Enmeduranki by the deities have a literary content and form identical to the revelations dispatched by Enmeduranki later to the people of Nippur, Sippar and Babylon:

vv. 7-9 ...They [deities] showed him [Enmeduranki] how to observe oil on water, a mystery of Anu, [Enlil and Ea], they gave him the tablet of the gods, the liver, a secret of heaven and [underworld], they put in his hand the cedar[-rod], beloved of the great gods...

vv. 13-15 ...he [Enmeduranki] showed them [people of Nippur, Sippar and Babylon] how to observe oil on water, a mystery of Anu, Enlil and Ea, he gave them the tablet of the gods, the liver, a secret of heaven and underworld, he put in their hand the cedar[-rod], beloved of the great gods... ${ }^{44}$

Helge Kvanvig observes that these two sections are deliberately set in parallel in order to emphasize the authority of the divinatory knowledge that was received from the gods in the heavenly assembly. ${ }^{45}$ The exact parallelism also stresses that the content of the knowledge transmitted to the $b \bar{a} r \hat{u}$ guild is precisely the same as the knowledge into which Enmeduranki was initiated by the gods.

The text shows that Enmeduranki's mediation is multifaceted and executed not only through a set of oral and written communication, but also through the establishment of distinct social and religious structures. It is noteworthy that Enmeduranki's instructions in the divinatory rituals to the people were preceded by the establishment of social settings ( «He set them on thrones before [him]») that mirror the social structure of the divine assembly. This detail was probably intended to stress the fact that the dispatching of esoteric information necessarily involves fixed hierarchical settings. The text also highlights the importance of the initiatory oath preceding the earthly initiation, since Enmeduranki «will bind his son whom he loves with an oath», and only after that he «will instruct him».

\footnotetext{
${ }^{44}$ LAMBERT, «Enmeduranki and Related Matters», 132.

${ }^{45}$ Kvanvig, Roots of Apocalyptic, 186.
} 
Finally, for this section, a comment should be made on the references to the tablet(s) found in the Nineveh text and their mediating role in the process of the transmission of the knowledge. The text mentions the tablet several times, treating it as an object given to Enmeduranki by the deities in the celestial realm and then dispatched by the seventh antediluvian hero to the ba $r \hat{r}$ guild and to his son. This tablet is a medium that has the capacity to cross the boundaries between the upper and lower realms, as well as the boundaries of the generations. This two-fold function of the tablet as the instrument able to bridge the vertical (heavenly and celestial) and horizontal (antediluvian and postdiluvian) gaps makes it possible for it to remain a pivotal symbol of mediation prominent in the Mesopotamian and Enochic traditions.

Kvanvig, after meticulously examining the similarities between the imagery of the heavenly tablet(s) in the Nineveh text and in early Enochic materials (1 Enoch 81 and the Epistle of Enoch), demonstrated that despite the different provenance of these traditions, their concepts of the tablet(s) exhibit striking parallels not only in general ideas but also in technical termino$\log \mathrm{H}^{46}$

\section{Enmeduranki as the Scribe}

The references to the tablets in the text from Nineveh mentioned above help us clarify another role of the seventh antediluvian hero that occupies a prominent place in the early Enochic traditions. This is the role of a scribe whose writings are predestined to cross the boundaries between the celestial and the earthly realms. Although the text from Nineveh does not explicitly label Enmeduranki as a scribe, several details of the king's description in this narrative seem to point to his connection to the scribal profession.

The first hint comes from the references to the celestial tablets that Enmeduranki receives in the assembly of gods. Pierre Grelot, in the section of his study dedicated to Enoch's scribal duties, observes that the «tablet of the gods, a secret of heaven and earth» recalls the celestial tablets given later to the patriarch Enoch. ${ }^{47}$ The imagery of the celestial and terrestrial tablets looms large in early Enochic materials and in some of them is directly linked with Enoch's scribal duties. Thus, 4Q203 8 refers to a «copy of the seco[n]d tablet of [the] le[tter...] by the hand of Enoch, the distinguished scribe...». ${ }^{48}$ The imagery of the tablet is combined here with the patriarch's title «distinguished scribe» (ספר פרשט). The passage, however, is very fragmentary and pro-

\footnotetext{
${ }^{46}$ KvanVIG, Roots of Apocalyptic, 76-79, 240-241.

${ }^{47}$ Grelot, «La légende d'Hénoch dans les apocryphes et dans la Bible: Origine et signification», 15.

${ }^{48}$ F. García Martínez - E. J. C. Tigchelaar (eds.), The Dead Sea Scrolls Study Edition, Leiden — New York - Köln 1997, vol. 1, 411.
} 
vides little information about the tablet. More extended evidence is preserved in 1 Enoch 81:1-6, where the motif of the celestial tablets coincides with two other themes: the patriarch's instructions to his son and Enoch's scribal activities. In this passage the patriarch, after reading the tablets in the upper realm, is brought by angels to the earth to instruct his son Methuselah and copy for him the content of the celestial tablets:

And he said to me: «O Enoch, look at the book of the tablets of heaven, and read what is written upon them, and note every individual fact». And I looked at everything in the tablets of heaven, and I read everything which was written, and I noted everything... And these three holy ones brought me, and set me on the earth before the door of my house, and said to me: «Tell everything to your son Methuselah... For one year we will leave you with your children, until you have regained your strength, that you may teach your children, and write (these things) down for them, and testify to all your children». ${ }^{49}$

The passage deals with three significant motifs: the celestial tablets, the instruction of Methuselah on earth, and Enoch's duties as the scribe who writes down the content of the tablets. An almost identical cluster of motifs is discernable in the pericope found in the text from Nineveh. Verses 19-22 describe Enmeduranki instructing his son in the divine secrets and then transferring to him a tablet and a stylus, the tools of the scribal profession: «the learned savant, who guards the secrets of the great gods, will bind his son whom he loves with an oath before Shamash and Adad by tablet and stylus and will instruct him». ${ }^{50}$

In these two strikingly similar accounts that deal with the initiation of the visionary's son, one detail should be noted: in both accounts the visionaries appear to be associated with the scribal profession. In the Enochic text it is made obvious by the explicit reference to the patriarch's writing activities, and in the Mesopotamian text by the implicit reference to a stylus, a scribal tool. ${ }^{51}$ This is supported further by the fact that in the Babylonian text the stylus is also tied to the role of the main character as the transmitter of esoteric knowledge to humans and particularly to his son. As will be shown later, in the Enochic writings three prominent roles of the patriarch as the scribe, the expert in secrets, and the mediator between the human and the divine realms also often appear together. The same cluster seems also observable in the tablet from Nineveh.

\footnotetext{
${ }^{49}$ KNIBB, The Ethiopic Book of Enoch, $186 \mathrm{f}$.

${ }^{50}$ LAMBERT, «Enmeduranki and Related Matters», 132.

${ }^{51}$ The reference to the stylus in this context might not only point to the scribal duties of the seventh antediluvian king but also show him in the role of initiating his son in the scribal activities.
} 


\section{Enmeduranki as the Priest}

As in the case with Enmeduranki's scribal role, only implicitly hinted at in the tablet from Nineveh, the discernment of his association with priestly duties also requires a certain exegetical effort. Before I engage in such an effort, however, I must briefly remark on the sacerdotal affiliations of the bārû practitioners. Alfred Haldar observes that «according to well-known King Enmeduranki tradition, the $b \bar{a} r u$ u priesthood originated in Sippar ... where the primeval King Enmeduranki ... received from Shamash and Adad the tablet of the Gods... Afterwards he caused the priests to enter [into the divination chamber?] and gave them the tablet...»..$^{52}$ The bārû guild was a priestly group that attached great importance to ritualistic purity. In connection with the $b \bar{a} r \hat{u}$, Haldar notes that «in order to approach the deity the priest had to be pure, ellu (i. e. holy); and this qualification was not acquired once and for all by initiation, but had to be renewed every time the priest was to officiate»..$^{53}$ The priestly affiliation of the group is also hinted at in the requirement that the $b \bar{a} r \hat{u}$ practitioner had to be free from certain blemishes. Mesopotamian texts warn that one «with defective eyes, or with a maimed finger shall not draw near to the place for deciding via bāruttu». ${ }^{54}$ These disqualifications bear some similarities to the priestly regulations found in Leviticus. One can see, however, that the bāru priesthood was different from the later Israelite priestly models attested in the biblical texts. Since the primary function of the $b \bar{a} r \hat{u}$ priests was to foretell the future, i. e., discern by various means the will of the gods, they can be also viewed, using Oppenheim's terminology, as oracle-priests. ${ }^{55}$

The purpose of this excursus into the priestly features of the $b \bar{a} r \hat{u}$ group was to show that this guild was viewed as a sacerdotal organization bound by distinctive rules of purity. Their rituals involving sacrificial animals during the extispicy rites also might point to their priestly affiliation. ${ }^{56}$

Keeping in mind the priestly function of the $b \bar{a} r \hat{u}$, this investigation must now return to the tablet from Nineveh. As mentioned earlier, this text starts

${ }^{52}$ Haldar, Associations of Cult Prophets, 1.

${ }^{53}$ Haldar, Associations of Cult Prophets, 2.

${ }^{54}$ Moore, The Balaam Traditions, 42.

${ }_{55}$ OpPenheIm, The Interpretation of the Dreams in the Ancient Near East, 221. The divinatory angle of $b \bar{a} r u$ priesthood is also stressed by Pierre Grelot who remarks that «the hereditary priesthood founded at Sippar is envisaged, therefore, essentially from the divinatory viewpoint, that of knowing the secrets of the gods, transmitted to humans by way of the oracles». GRELOT, «La légende d'Hénoch dans les apocryphes et dans la Bible: Origine et signification», 8.

${ }^{56}$ H. W. F. SAgGs, The Greatness That Was Babylon: A Sketch of the Ancient Civilization of the Tigris-Euphrates Valley, London: Sidgwick and Jackson, 1962, $347 f$. 
with the statement that explicitly identifies the seventh antediluvian king of Sippar with the cult of the solar deity Shamash and his prominent ancient temple Ebabbara situated in Sippar. The tablet states that Enmeduranki was appointed by the solar deity Shamash in his temple Ebabbarra (the house of the rising sun). It does not, however, directly refer to Enmeduranki's priestly duties in the temple or name him as a priest of Shamash.

The motif of Shamash's priesthood nevertheless appears in the last section of the text (vv. 22-29). Here the «offspring of Enmeduranki» is defined as a «long-haired priest» who «may approach the presence of Shamash and Adad»:

When a diviner, an expert in oil, of abiding descent, offspring of Enmeduranki, king of Sippar, who set up the pure bowl and held the cedar[-rod], a benediction priest of the king, a long-haired priest of Šamaš as fashioned by Ninhursagga, begotten by a nišakku-priest of pure descent: if he is without blemish in body and limbs he may approach the presence of Šamaš and Adad where liver inspection and oracle (take place). ${ }^{57}$

Helge Kvanvig observes that in this section of the text the ancestry and the legitimacy of the priesthood are traced to the seventh antediluvian king since the tablet indicates that «the process of transmission will continue in the line of priestly descendants from Enmeduranki ${ }^{58}$ until the priesthood at the time of the author»..$^{5}$

The idea that Enmeduranki's initiation into the assembly of the gods might mark the beginning of the priestly line is significant for a possible association of the king with the priestly office. In this context one important detail must be mentioned. Line 29 of the tablet from Nineveh depicts a priest without «blemish in body and limbs» approaching the presence (mahar) of Shamash and Adad. The reference to the «presence» (mahar) is intriguing since it recalls the exact terminology used earlier in the text in describing Enmeduranki's approach to the presence of both deities in the celestial realm. Similarly in the text cited above, Enmeduranki is depicted as the one «who sat in the presence (mahar) of Shamash and Adad, the divine adjudicators». ${ }^{60}$

In view of these parallels it is possible that Enmeduranki might have been considered by the authors of the tablet as a celestial model for the earthly priesthood who, in the distant past, entered for the first time the presence of

${ }^{57}$ LAMBERT, «Enmeduranki and Related Matters», 132.

${ }^{58}$ Pierre Grelot stresses the «liturgical» character of the teaching of the seventh antediluvian hero which he transmits to his sons: «... ainsi initié aux fonctions divinatoires du sacerdoce, il y consacre ses fils à leur tour et leur enseigne les formules liturgiques». Grelot, «La légende d'Hénoch dans les apocryphes et dans la Bible: Origine et signification», 8 .

${ }^{59}$ Kvanvig, Roots of Apocalyptic, 188.

${ }^{60}$ LAMBERT, «Enmeduranki and Related Matters», 128 and 130. 
Shamash and Adad in the celestial realm. In this context the terrestrial priesthood can be seen as the counterpart of this celestial prototype. This possibility is supported by several scholarly suggestions that the text from Nineveh claims that the present priests are physical descendants of the primeval king Enmeduranki. ${ }^{61}$ This concept of the sacerdotal pedigree parallels the later Enochic traditions attested in 2 Enoch, ${ }^{62}$ which construe the earthly priestly line as physical descendants of the seventh antediluvian patriarch.

\section{SUMMARY}

In view of the importance of the Ethiopic Book of Enoch for a number of fields of Oriental Studies, and as a contribution to the ongoing discussion about the reasons for the preservation of this book in the Ethiopian tradition, the article focuses on a possible prototype of Enoch's figure reflected in the Mesopotamian lore about the mythical King Enmenduranki, depicted there as a diviner, an expert in secrets, a mediator between gods and humans, a scribe, and a priest. The story of Enmenduranki and his functions are investigated on the basis of a tablet from Nineveh, one of the most important documents of the Enmeduranki's tradition, dated prior to 1100 B.C. The article discusses the cultural context of Mesopotamia during the second millennium B.C., where the Enmeduranki's tradition was originated.

${ }^{61}$ Kvanvig, Roots of Apocalyptic, 186.

${ }^{62}$ It is intriguing that 2 Enoch 59 depicts the patriarch as the one who instructs his sons in the sacrificial halakot pertaining to the priestly rituals. 